\title{
Research on Engineering Cost Pricing and Control in Design Stage of Construction Project
}

\author{
Cao Jinbao \\ (Nanchang Institute of Technology, Nanchang 330044)
}

Keywords: Construction Project; Design Stage; Engineering Cost; Pricing; Control

\begin{abstract}
With the rapid growing of economic development, the engineering industry has shown a good development trend. In the development process of engineering industry, the engineering cost pricing and control in design stage of construction project have become a crucial topic. It have an inestimable impetus, and is of great significance to the work in design stage of construction project how to improve effectiveness of engineering cost pricing and control in design stage of construction project and promote the social benefits of project and the economic benefits. In this paper, the problems related to engineering cost control in design stage of construction project are mainly analyzed, reasonably handled and controlled within the reasonable limits to maximize the project benefits.
\end{abstract}

\section{Introduction}

Engineering cost management is one of the important components of construction management. It has become an important issue in project construction how to exactly determine and effectively control the project investment. For a long time, with the implementation of tendering system and the perfecting quota system, the remarkable results have been obtained. With the rapid development of commodity economy, the capital construction also has developed fast. However, the capital construction investment is out of control with different degrees. The phenomenon of "three excesses" occurs repeatedly. At present, engineering cost control is mainly applied in project implementation (construction) and construction stage. Almost only construction budget and settlement are focused, and the cost control before construction is ignored; only the construction is focused, and the design is ignored; only bargaining and lower price are focused, and the scientific and reasonable pricing are ignored; only the method of cost control is focused-Is it the real control, and the nature is ignored. Finally, because of the path of the cart before the horse, the cost control effect is not ideal. There are many reasons for the disruption and overspending in project investment management. But it is a very important factor to ignore project cost control in design stage of construction project. However, to seek the effective method for engineering cost pricing and control in design stage of construction project, this paper analyzes the significance of engineering cost pricing and control in design stage of construction project, discusses the methods of engineering cost pricing and control in design stage of construction project and proposes the optimization strategy for engineering cost pricing and control in the same stage.

\section{Significance of Engineering Cost Pricing and Control in Design Stage of Construction Project}

In the early stage of construction project, the corresponding design work should be performed in accordance with the demands for construction project and related standards. Project design work is a relatively complex system in which the corresponding design drawings and documents are involved. The staff of construction project should get know the design intention of project and perform the comprehensive planning from the point of microscopic. This point is critical, because it will involve many economic and technical factors, and directly decide the final engineering quality. In design stage of construction project, the staff need to know the engineering cost and the corresponding control requirements. This is the basis and standards for improvement of design quality of construction project.

After completion of technical design, the managerial staff of construction project need to work 
out project budget in accordance with the construction site situation of project and market price to understand the overall factor of engineering cost and well realize the effective control of engineering cost.

It is of some importance to all aspects of the project's development to strengthen engineering cost pricing and control in design stage of construction project: (1) To save engineering cost and promote the economic benefits. Through engineering cost pricing and control in design stage of construction project, expenses and costs of project can be comprehensively analyzed to promote the good economic benefits for project. In the engineering development stage, a financial loss to engineering development is easily made if the cost budget and control of construction project are not in place. (2) It can improve the engineering budget management to strengthen engineering cost pricing and control. Through engineering cost pricing and control in design stage of construction project, the financial management and operation capacities in engineering development can be improved by comprehensively adjusting the budget program of project, working out the reasonable financial budget plan and balancing the financial expenditure and gains.

\section{Problems and Causes in Current Engineering Cost Control}

(1)Lack of Conceptual Attention. In project construction, only the cost control in construction stage is focused, and the engineering cost management in design stage of construction project is ignored, that lead to limited input of all aspects. This problem is due to the excessive attention for all aspects of input in the construction stage. The staff think that if only they well control the input and the related fees in construction stage, the effective control for engineering cost will be realized. Therefore, construction budget and settlement are ignored by the main bodies.

(2)Backward Design Idea. Design institution and personal qualities are very crucial for engineering project. But in practice, to reduce risk and quality concern, many designers adopt the very conservative design manners. This may lead to unreasonable layout and serious wasteful investment.

(3)Frequent and Multiple Design Modifications. The project vulnerabilities and errors are due to the incomplete and shallow research work, imperfect design of related profession, low design level and imperfect verification system in early stage of design. Therefore, the design modification s in the later stage of design increase the cost of construction project.

(4)Lack of Scientific Combination of Engineering Technology and Cost. In current design institutions, for the design technology to which much attention has been paid by many designers, the principle of economy is ignored, and the engineering cost is lack of concern. Due to that many designers are lack of economy thought, the economy of design can not be exemplified fully. For the budgeteers, if they have not new skilled technology of engineering, intimate knowledge about various processes and links of construction project and strong grasp of various processes and links, they must not realize the reasonable, effective and scientific control of engineering cost.

\section{Engineering Cost Pricing and Control Methods in Design Stage of Construction Project}

\section{(1)Adopting Quota Design}

The cost control method frequently used by most engineering designers is quota design in design stage of construction project. The main content of quota design and the general relationship between them: combined the planed engineering construction plan, project size and project investment, the limit value is set within the expected range. Generally, the limit value is a little higher than the current cost of design engineering.

\section{(2)Strengthening Management of Design Modification}

To strengthen the management of design modification. Everything is in the process of development and changing. Due to many influence factors such as the natural disasters, construction safety incident and optimization and reconstruction of engineering design, the project can not be basically implemented according to the original plan. In a word, the schedule change of project engineering is faster. 


\section{(3)Attaching Importance to the Overall Design of Project}

In project design stage, it is wrong to only realize the budget and control of single construction link. In order to improve the project cost counting and control capability in project design stage and provide more safeguards for good development of project, the overall design of project engineering must be considered. It can be realized by setting small goals. Firstly, the purchase cost of cheap raw materials should be controlled within a certain range, then the reasonable control and handling should be performed for other aspects of project. Design is an important link of engineering design, and in which different structural styles are generally adopted. Therefore, the engineering costs of different floors and units are different. If the reinforced concrete frame structure is adopted, the seismic capacity and durability of building structure are better than that of the masonry-concrete structure. But the latter has the advantages such as low steel consumption and low cost.

\section{(4)Strengthening Joint Examination for Drawings}

If the designed depth of drawings is not enough, or it is not imperfect, many design modifications would be needed in construction stage. This will increase the cost of project. Controlling the engineering change as much as possible before construction, overcoming the shortcomings and deficiencies of design program in design stage, the best results will be obtained with the lowest cost. After drawings examination, a negotiation for revised design is needed to minimize the design modifications of project and avoid the loss of cost control.

\section{Conclusion}

In early stage of engineering construction, design unit and designers should build the concept of economy accounting, overcome the wrong idea of focusing engineering technology and ignoring the economy of project, bind cost management and construction together, strictly estimate tasks according to the designed investment and compare several programs within the approved design budget limit to reduce and control the project investment as much as possible. For the project cost management, the comparative analysis between the current construction cost and the project investment in early stage of project design should be carried out timely, and the feedback cost information and the positive design modifications should be realized for effective usage and control of investment. Only the project cost control is carried out in early stage of design, the project cost can be effectively controlled. In project design stage, it have positive influence on the development of project engineering to carry out engineering cost pricing and control. In a word, the saving in design stage of project is the biggest saving of the whole project.

\section{References:}

[1]Aliverdi R, Naeni L M, Salehipour A. Monitoring project duration and cost in a construction project by applying statistical quality control charts[J]. International Journal of Project Management, 2013, 31(3):411-423.

[2]Olaniran $\mathrm{O}$ J. The effects of cost-based contractor selection on construction project performance[J]. Journal of Financial Management of Property \& Construction, 2015, 20(3):235-251.

[3] Hu W, He X. An Innovative Time-Cost-Quality Tradeoff Modeling of Building Construction Project Based on Resource Allocation[J]. The Scientific World Journal,2014,(2014-1-30), 2014, 2014(2014):673248.

[4]Xu S, Liu K, Tang L C. Applying Organizational Semiotics for Developing Knowledge-Based Cost Estimation of Construction Project[C]// International Conference on Informatics and Semiotics in Organisations. 2016:80-91.

[5]Arif F, Lodi S H, Azhar N. Factors influencing accuracy of construction project cost estimates in Pakistan: Perception and reality[J]. International Journal of Construction Management, 2015, 15(1):59-70.

[6]Fawcett W, Urquijo I R, Krieg H, et al. Cost and Environmental Evaluation of Flexible Strategies for a Highway Construction Project under Traffic Growth Uncertainty[J]. Journal of 
Infrastructure Systems, 2015, Published online(3):692.e7-692.e13.

[7]Sun C, Man Q, Wang Y. Study on BIM-based construction project cost and schedule risk early warning[J]. Journal of Intelligent \& Fuzzy Systems, 2015, 29(2):469-477.

[8]Xu S, Liu K, Tang L C. Applying Organizational Semiotics for Developing Knowledge-Based Cost Estimation of Construction Project[C]// International Conference on Informatics and Semiotics in Organisations. 2016:80-91.

[9]Ramli Z, Hanipah M H, Zawawi M H, et al. Cost Comparison On Industrialized Building System (Ibs) And Conventional Method For School Construction Project[J]. Journal of Scientific Research \& Development, 2016, 3(4):95-101.

[10]Ma H. Based on value engineering in the whole life cycle of the construction project cost control[J]. Shanxi Architecture, 2017.

[11]Zhang R. Analysis of Dynamic Management and Control Strategy of Construction Project Cost [J]. Value Engineering, 2018.

[12] Fu S L. Construction project management and project cost control[J]. Journal of Jiamusi Vocational Institute, 2017. 